\title{
SERUM FIBRINOGEN LEVELS AND ITS RELATION TO DIABETIC RETINOPATHY
}

\author{
Adil Majeed Mir ${ }^{1}$, Sabia Rashid², Aamir Rashid³, Raashid Maqbool4, Mukhtar Ahmad5 ${ }^{5}$ Waseem Rashid6, Mohammad Mustafa ${ }^{7}$, \\ Ujala Gulzar 8
}

${ }_{1}^{1}$ Post Graduate Student, Department of Ophthalmology, Govt. Medical College, Srinagar.

${ }^{2}$ Professor, Department of Ophthalmology, Govt. Medical College, Srinagar.

${ }^{3}$ Post Graduate Student, Department of Medicine, SKIMS Soura, Srinagar.

${ }^{4}$ Post Graduate Student, Department of Ophthalmology, Govt. Medical College, Srinagar.

${ }^{5}$ Post Graduate Student, Department of ENT, Govt. Medical College, Srinagar.

${ }^{6}$ Senior Resident, Department of Ophthalmology, SKIMS Medical College, Srinagar.

${ }^{7}$ Lecturer, Department of Statistics Ophthalmology, Govt. Medical College, Srinagar.

IIntern, Govt. Medical College, Srinagar.

\section{ABSTRACT}

\section{BACKGROUND}

Elevation of plasma fibrinogen is thought to be one of the major risk factors associated with increase in blood viscosity in patients with diabetic retinopathy. Diabetic retinopathy being a microangiopathy, the study was done with the aim to assess the relationship between serum fibrinogen levels in patients with and without diabetic retinopathy.

\section{MATERIALS AND METHODS}

This study was conducted at Government Medical College, Srinagar, in which 101 diabetic patients with and without retinopathy were evaluated. These patients were classified into two groups:

1) Patients with diabetic retinopathy, which included 50 patients.

2) Patients without diabetic retinopathy, which included 51 patients.

Each patient was subjected to a comprehensive ocular examination and the results were recorded and analyzed in detail.

\section{RESULTS}

Our study which was prospective, non-randomized hospital based study was undertaken for the period of 18 months to see the association between fibrinogen levels in the blood and the development of diabetic retinopathy. Our study included 101 patients with type- 2 diabetes. Among this Group-1 included 50 patients with diabetic retinopathy and Group-2 included 51 patients without diabetic retinopathy. In our study, total number of female patients were $65(64.35 \%)$ and males were $36(35.64 \%)$. The mean age for males and females was 57.5 and 54.6 years respectively. Mean duration of diabetes in patients with retinopathy and without retinopathy was 10.9 and 5.7 years respectively. It was observed in our study that most of the patients with diabetic retinopathy had compromised visual acuity in one or both eyes, i.e., $\mathrm{V}_{\mathrm{n}}>6 / 60$. We found that out of 50 patients with diabetic retinopathy, $36(72 \%)$ patients were having raised serum fibrinogen levels, while as out of 51 patients without diabetic retinopathy 17 (33.33\%) patients were having raised serum fibrinogen levels, and mean serum fibrinogen levels in patients with and without retinopathy was $5.310 \mathrm{~g} / \mathrm{l}$ and $3.783 \mathrm{~g} / \mathrm{l}$, thus fibrinogen levels were significantly higher in diabetics with retinopathy $(\mathrm{p}<0.001)$.

\section{CONCLUSION}

High plasma fibrinogen levels contribute significantly to the development of diabetic retinopathy.

\section{KEYWORDS}

Diabetes Mellitus, Diabetic Retinopathy, Serum Fibrinogen.

HOW TO CITE THIS ARTICLE: Adil Majeed Mir, Sabia Rashid, Aamir Rashid, Raashid Maqbool, Mukhtar Ahmad, Waseem Rashid, Mohammad Mustafa, Ujala Gulzar. "Serum Fibrinogen Levels and its Relation to Diabetic Retinopathy." Journal of Evolution of Medical and Dental Sciences 2015; Vol. 4, Issue 95, November 26; Page: 16036-16044, DOI: 10.14260/jemds/2015/2341.

\section{INTRODUCTION}

Diabetic retinopathy is the progressive dysfunction of the retinal vasculature caused by chronic hyperglycemia. ${ }^{1}$ Diabetic retinopathy is a common and specific microvascular complications of diabetes and remains the leading cause of vision loss world wide. ${ }^{2,3}$ Although, diabetes affects the eyes in many ways, diabetic retinopathy is the most common and serious ocular complication.

Financial or Other, Competing Interest: None.

Submission 07-11-2015, Peer Review 09-11-2015,

Acceptance 16-11-2015, Published 24-11-2015.

Corresponding Author:

Aamir Rashid,

House No. 8, LD Colony, Rawalpora,

Srinagar-190005, J \& K. India,

E-mail: aamirrashid11@yahoo.co.in

DOI:10.14260/jemds/2015/2341.
Among all the diabetics, about a third have signs of diabetic retinopathy and a third of these might have vision threatening retinopathy defined as severe retinopathy or macular oedema.4,5 Apart from its effects on vision, the presence of diabetic retinopathy also signifies a heightened risk of life threatening macrovascular complications. ${ }^{6}$

A number of risk factors associated with diabetes mellitus have been found to contribute or accelerate the process of retinopathy. These include hyperglycaemia, hypertension, dyslipidaemia, duration of diabetes, pregnancy, puberty and cataract surgery. ${ }^{7}$ In addition to the above mentioned risk factors, diabetics have been found to have increased blood viscosity, especially in those having diabetic retinopathy. Diabetes may induce procoagulant expression by vascular endothelium, thereby increasing formation of fibrin and delaying tissue repair following injury. 
However, there are also indications of a deviation of the haemostatic balance within the vascular system associated with a systemic rather than a local prothrombotic/ procoagulant state coagulation activation results in formation of thrombin from prothrombin. This involves several coagulation factors, mainly elevated plasma fibrinogen levels, activated platelets and hypofibrinolysis. ${ }^{8}$ Among the various factors studied, plasma fibrinogen was found to be raised causing increased blood viscosity, especially in diabetic retinopathy.

Fibrinogen is a glycoprotein of a molecular weight of approximately $3,40,000$ Daltons, present in plasma at concentration in the range of 2 to $4 \mathrm{~g} / \mathrm{l}(200-400 \mathrm{mg} / \mathrm{dl}) \cdot{ }^{9}$ It is synthesis in liver ( 1.7 to $5 \mathrm{~g} /$ day). ${ }^{10}$ It is converted by thrombin into fibrin during blood coagulation. ${ }^{11}$ The half-life of fibrinogen is about 3-5 days.

The synthesis of fibrinogen is controlled by the gene, which codes for the $\beta$-chain synthesis. ${ }^{9}$ An increase in fibrinogen levels is found in cases of diabetes, inflammatory syndrome, obesity. ${ }^{12}$ A decrease of fibrinogen level is observed in DIC, fibrinogenolysis. ${ }^{9}$ Prolonged poor metabolic control leads to chronic fibrinogen hypersecretion. In addition increased levels of inflammatory factors can cause further increases in fibrinogen levels and increased coagulation activation associated with increased fibrinogen For this latter process, anticoagulant treatment improves the situation; however, in incipient diabetic nephropathy anticoagulation has no effect.

The general idea is that improved glycaemic control will reduce fibrinogen levels. Fibrinogen is a recognised risk factor for macrovascular disease and increased levels may exert effects through a variety of mechanisms including increased blood viscosity, increased size of fibrin clots, increased tissue deposition and stimulation of atherosclerosis and vascular thickening thus involved in the pathogenesis of thrombotic cardiovascular events. ${ }^{12}$ Some of these mechanisms may also be relevant to micro-angiopathy.

Thus increased fibrinogen levels may contribute to the observed increased prevalence of micro-thrombosis in the retinal capillaries of diabetic individuals. In diabetes, increased capillary leakage may further increase the exposure of tissue to increases in fibrinogen and in the case of coagulation it may increase fibrin deposition. In addition to increased level, fibrinogen modification of fibrinogen and fibrin also plays an important role.

Thus fibrin deposition may be increased when glycated fibrinogen is involved, since this has a reduced susceptibility to plasmin. It has been reported that glycation of fibrinogen may result in a fibrin network with a reduced porosity and reduced fibre thickness, which results in a reduced lysability of clots. ${ }^{13}$

\section{MATERIAL AND METHODS}

Our study was a prospective hospital based non-randomized study. This study was conducted at Department of Ophthalmology, Government Medical College, Srinagar, which is the sole referral tertiary care hospital for the Kashmir Valley. The study was conducted for a period of 18 months from August 2011 to January 2013. Approval was taken from the institutional ethics committee for the study.

\section{Inclusion Criteria}

- Known cases of diabetes,

- Newly diagnosed cases with Fasting Blood Sugar (FBS) $\geq 126 \mathrm{mg} \%$ or Post-Prandial Blood Sugar (PPBS) $\geq 200 \mathrm{mg} \%$.

\section{Exclusion Criteria}

- Systemic illnesses altering the blood coagulation profile.

- Inherited diseases, which cause either hypercoagulability or bleeding tendencies.

- Patients on anticoagulants.

- Severe liver, cardiac or renal failure.

- Patients with opacities of media obstructing view of the fundus.

Complete history of the patients regarding the ocular complaints, type of diabetes, duration of diabetes and treatment and other systemic illnesses were noted. Any previous history of eye surgery, eye trauma and any laser treatment were recorded. History of diabetes in the family was noted.

On examination, visual acuity was done at six meters distance with Snellen chart. E-chart was used for illiterate people. Examination of the eye in diffuse light was done to detect any gross abnormality of anterior segment. Slit lamp examination was done in every patient in a systematic manner, status of conjunctiva, cornea, anterior chamber, iris, pupillary reaction and lenticular status was noted. Intraocular pressure was recorded in every patient. Detailed fundus examination with direct and indirect ophthalmoscopy was done. Fundus fluorescein angiography was done as and when indicated. Investigations like FPG (Fasting Plasma Glucose), PPPG (Post Prandial Plasma Glucose) and Plasma Fibrinogen were done.

Based on the fundus examination findings, the patients were classified into two groups for comparison:

1) Group 1: Diabetics with retinopathy,

2) Group 2: Diabetics without retinopathy.

Patients in Group 1 were graded as per the ETDRS (Early Treatment Diabetic Retinopathy Study) classification of diabetic retinopathy. ${ }^{14}$ If a patient had different grades of retinopathy in both eyes, the more severe grade was taken into consideration.

\section{ESTIMATION OF PLASMA FIBRINOGEN:}

Test Principle: In presence of excess of thrombin, the clotting time of diluted plasma has a direct bearing on the level of plasma fibrinogen. ${ }^{15,16}$

\section{PROCEDURE}

Specimen Collection and Treatment

- A $2 \mathrm{ml}$ of venous blood was collected, from which 9 volume blood was mixed with 1 volume of trisodium citrate anticoagulant.

- Centrifugation is done for 10 minutes at $2500 \mathrm{~g}$.

- Plasma so obtained is diluted with sodium azide buffer in $1: 20$ dilution $(0.1 \mathrm{ml}$ plasma $+1.9 \mathrm{ml}$ of buffer solution).

- $100 \mu \mathrm{l}$ of processed plasma is then mixed with $50 \mu \mathrm{l}$ lyophilized titrated calcium thrombin containing a specific heparin inhibitor to allow the assay of fibrinogen in heparinized plasma samples.

- Assay results were shown by the stago autoanalyser coagulometer. The normal plasma fibrinogen level ranges from 2 to $4 \mathrm{~g} / \mathrm{l}$.

\section{STATISTICAL ANALYSIS}

Statistical software GraphPad InStat-3 and primer of biostat was used for stastistical analysis. The data was expressed as mean $( \pm S D)$ and percentage values as necessary. Statistical method involved included independent student-t test for normally distributed continuous variables and the Pearson Chi-square test or two tailed Fisher exact test for categorical variables. 
ANOVA was used for comparison of more than two continuous variables. All the values were calculated as twotailed; a $P$ value $<0.05$ was considered statistically significant.

\section{RESULTS}

The total number of patients included in our study where 101 in which females were $65(64.35 \%)$ and males were 36 (35.64\%). The mean age for males was 57.5 years and females was 54.6 years, $66.33 \%$ of cases in our study were between 41-60 years of age (Table-1 and Fig 1). Mean duration of diabetes in patients with and without retinopathy was 10.9 and 5.7 respectively. Total number of diabetic patients with and without retinopathy were 50 and 51 respectively.

There was statistical significant relationship between duration of diabetes and development of diabetic retinopathy $\mathrm{p}<0.001$ (Table-2 and Fig 2). Total number of males with and without retinopathy in our study were 16 and 20 respectively and total number of females with and without retinopathy in our study were 34 and 31 respectively, but there was no statistically significant relationship of diabetic retinopathy with sex $(p=0.449)$ (Table-3 and Fig 3$)$. It was seen that most of the patients with diabetic retinopathy had compromised visual acuity in one or both eyes, i.e. $V_{n}>6 / 60$ lying in red zone of bar plot, while as few patients were having good visual acuity, i.e. visual acuity between 6/6 to 6/9P lying in green zone of bar plot; vice versa was true in patients without retinopathy (Table-4 and Fig 4).

In our study, out of 50 patients with diabetic retinopathy $36(72 \%)$ patients were having raised serum fibrinogen levels, while as $14(28 \%)$ were having normal serum fibrinogen levels. In comparison out of 51 patients without diabetic retinopathy, $17(33.33 \%)$ patients were having raised serum fibrinogen levels while as $34(66.66 \%)$ were having normal serum fibrinogen levels. Mean serum fibrinogen levels in patients with and without retinopathy was $5.310 \mathrm{~g} / \mathrm{l}$ and $3.783 \mathrm{~g} / \mathrm{l}$. The difference in the mean values of serum fibrinogen levels in patients with and without diabetic retinopathy was statistically significant $(\mathrm{p}<0.001)$ (Table-5 and Fig 5 A and B).

Also when relationship between serum fibrinogen levels and fasting blood sugar level was seen, $65.11 \%$ of patients having normal blood sugar fasting levels had normal serum fibrinogen levels and $65.51 \%$ of patients having raised blood sugar fasting levels also had raised serum fibrinogen levels. On comparing the mean serum fibrinogen level of patients with normal and raised fasting blood sugar levels which came out to be $3.995 \mathrm{~g} / \mathrm{l}$ and $4.942 / \mathrm{l}$ respectively, significant difference was seen between two groups $p=0.003$ (Table- 6 and Fig 6).

\section{DISCUSSION}

During the past decade the potential role of haemostatic factors, particularly fibrinogen in diabetic retinopathy has gained considerable interest. ${ }^{17}$

It has been established through several cross-sectional prospective epidemiological studies. ${ }^{18}$ that plasma fibrinogen concentration is a strong and independent cardiovascular risk factor along with other risk factors. As elevated serum fibrinogen is well established risk factor for macrovascular diseases, various studies have been conducted to evaluate its role in microangiopathies.

Thus our study which was prospective, non-randomized hospital based study intended to see the association between fibrinogen levels in the blood and the development of diabetic retinopathy. Our study included 101 patients with type-2 diabetes. Among this Group-1 included 50 patients with diabetic retinopathy of varying severity and Group- 2 included 51 patients without diabetic retinopathy.
The serum fibrinogen levels of two groups were compared and it was seen that serum fibrinogen was significantly raised in the patients with diabetic retinopathy. These results were consistent with results of the various studies in the past like one of the study carried out by $\mathrm{T}$. Fujisawa, et al. and Asakawa, et al.19,20 Their data suggest that in patients with type $2 \mathrm{DM}$, an increased blood viscosity due to high fibrinogen level as well as an elevated intravascular pressure play a role in the development of diabetic retinopathy and also recent study conducted by Kuzhuppilly, et al. ${ }^{21}$ which also concluded that high plasma fibrinogen levels contribute significantly to the development of diabetic retinopathy.

In our study total number of female patients were $65(64.35 \%)$, which outnumbered males $36(35.64 \%)$, but their mean ages were comparable 54.6 years and 57.5 years respectively (Table-1). There was no statistically significant relationship of diabetic retinopathy with sex $p=0.449$ (Table-3).

The difference in the mean ages of the patients with and without diabetic retinopathy was 54.64 years and 56.11 years, both the groups had similar age distribution pattern and no significant difference existed between them. These findings were consistent with the previous study. ${ }^{22}$

Also no statistical significance in mean age of males and females was found $\mathrm{p}=0.204$ (Table-1). On the other hand, it was seen that duration of diabetes was significantly related to the development and progression of retinopathy $\mathrm{p}<0.001$ (Table-2). These findings are consistent with results of other studies, which have established that the duration of diabetes is an important factor in the development of diabetic retinopathy. ${ }^{23,24,25}$

In our study we found that visual acuity of group 1 was compromised in one or both eyes in comparison to group 2 ; as when visual acuity of 100 eyes of group 1 was evaluated $37(37 \%)$ eyes were having visual acuity of $6 / 60$ or above in comparison to 102 eyes of group 2 were only 7(6.86\%); eyes were having visual acuity of $6 / 60$ or above. Thus indicating burden of visual loss due to retinopathy. In our study, treatment profile of patients showed that $66(65.34 \%)$ of patients were on oral hypoglycemic, $8(7.92 \%)$ were exclusively on insulin and 27(26.73\%) were on both Fig 7 .

On analyzing the serum fibrinogen levels, it was seen that the number of patients with raised serum fibrinogen levels were significantly higher in retinopathy group $36(72 \%)$ than patients without retinopathy $17(33.33 \%)$. Also mean serum fibrinogen levels in patients with retinopathy was higher $(5.310 \mathrm{~g} / \mathrm{l})$ than patients without retinopathy $(3.783 \mathrm{~g} / \mathrm{l})$.

Thus serum fibrinogen levels of two groups showed statistically significant relationship $\mathrm{p}<0.001$ (Table-5). On further comparison within the retinopathy group, no significant difference was seen between the NPDR and PDR groups, suggesting that plasma fibrinogen may not contribute to the severity of retinopathy $\mathrm{p}=0.403$ (Table-7). This finding is in agreement with the reports of Fujisawa and Asakawa. ${ }^{19,20}$

They found that plasma fibrinogen is independently associated with existence of diabetic retinopathy, but not significantly different when comparing different grades of retinopathy. Also duration of DM, which was seen to be the most important risk factor in our study for the development of retinopathy did not show any correlation with plasma fibrinogen levels $p=0.335$ (Table-8, Fig 8), indicating that their contributions are independent of each other. The results were consistent with study conducted by Kuzhuppilly, et al.21

It was also seen in our study that significant correlation exists between the plasma fibrinogen levels and fasting glucose levels. 
As mean serum fibrinogen levels in patients with raised and normal fasting blood sugar values are $4.942 \mathrm{~g} / \mathrm{l}$ and $3.995 \mathrm{~g} / \mathrm{l}$ respectively, the difference between the mean serum fibrinogen levels of two groups is statistically significant $\mathrm{P}=0.003$ (Table-7).

In our study, difference in the mean serum fibrinogen level of male $(4.079 \mathrm{~g} / \mathrm{l})$ and female $(4.794 \mathrm{~g} / \mathrm{l})$ seems to be significant as $p=0.033$, but the statistical result was under powered, thus statistical significance between two groups is questionable and can be due to the fact that female patients outnumbered male patients in our study population.

\section{CONCLUSION}

It was concluded from the current study, that diabetic retinopathy is independently associated with higher plasma fibrinogen even after controlling the other major risk factors of diabetes. The result seen thus opens new avenues for more studies regarding therapies and management strategies aimed at altering the blood viscosity and preventing microvascular occlusion. Estimation of plasma fibrinogen is a simple cost effective procedure that if established as a marker for retinopathy and proven modifiable would probably be of great benefit in controlling if not preventing the sight claiming disease of diabetic retinopathy. Nevertheless larger clinical trials and studies are required before this hypothesis can be established and plasma fibrinogen can become a dependable and modifiable risk factor in the pathogenesis of diabetic retinopathy.

\section{BIBLIOGRAPHY}

1. Klein $\mathrm{R}$, Klein $\mathrm{B}$, Moss $\mathrm{S}$, et al. The Wisconsin epidemiologic study of diabetic retinopathy ten-year incidence and progression of diabetic retinopathy. Arch Ophthalmol. 1994;112:1217-28.

2. Congdon NG, Friedman DS, Lietman T. Important causes of visual impairment in the world today. JAMA 2003;290:205-60.

3. Fong DS, Aiello LP, Ferris FL, et al. Diabetic retinopathy. Diabetes Care 2004; 27: 2540-53.

4. Wild S, Roglic G, Green A, Sicree R, King H: Global prevalence of diabetes: Estimates for the year 2000 and projections for 2030. Diabetes care 2004;27:1047-1053.

5. Saaddine JB, Honeycutt AA, Boyle JP, et al. Projection of diabetic retinopathy and other major eye diseases among people with diabetes mellitus: United States, 2005-2050. Arch Ophthalmol 2008;126:1740-47.

6. Cheung N, Wong TY. Diabetic retinopathy and systemic vascular complications. Prog Retin Eye Res 2008;27:16176.

7. Ning Cheung, Paul Mitchell, Tien Yin Wong. Diabetic Retinopathy. Lancet 2010;376:124-36.

8. Cornelis Kluft and Jorgen Jespersen Review: Diabetes as a procoagulant condition. British Journal of Diabetes and Vascular Disease 2002;2:358.

9. Samama M, Conard J, Horellou MH. "Physiologie et exploration de h'hemostase. Paris : doin, 123-137, 153155, 1990.

10. Hantgan RR, Francsis CW, Scheraga HA, et al. Fibrinogen structure and physiology in "hemostasis and thrombosis basic principle and clinical practice" JB Lipincott company, 269-288, 1987.
11. Collet JP, Soria J, Mirshahi M, Hirsch M, et al. "Dusart syndrome: a new concept of the relationship between fibrin clot architecture and fibrin clot degradability: hypofibrinolysis related to an abnormal clot structure" blood 82,8,2462-2469.1993.

12. Alessi MC, Aillaud MF, Juhan-Vague I, "Fracteurs derisqué thrombogenes et atherosclerose" Feuil.bioi.,XXXV,197,3941,1994.

13. Ernst E, Resch KL, "Finrinogen as a cardiovascular risk factor: a meta-analysis and review of the literature." Ann.intern.Med.,118,12.956-963,1993.

14. Grading diabetic retinopathy from stereoscopic color fundus photographs- an extension of the modified Airlie House classification. ETDRS report number 10. Early Treatment Diabetic Retinopathy Study Research Group. Ophthalmology 1991;98:786-806.

15. Destaing F, Duzer A, Ferrand B, Portier A. Dosage du fibrinogen, A.Clauss, Pathol Biol, 8, 17/18, 1615-1621, 1960.

16. Caen J, Larrieu MJ, Samama M, L'hemostase methods Paris: L'Expansion scientifique, 215-218, 1975.

17. Antanio Ceriello. Fibrinogen and diabetes mellitus. Is it time for intervention trials? Diabetologia; 1997;40:731734.

18. OP Ganda and CF Arkin. Hyperfibrinogenemia: an important risk factor for vascular complications in diabetes. Diabetes Care; 1992;15(10):1245-1250.

19. Asakawa H, Tokunaga K, Kawakami F. Elevation of fibrinogen and thrombin-antithrombin III complex levels of type 2 diabetes mellitus patients with retinopathy and nephropathy. J Diabetes Complications 2000;14:121-6.

20. Fujisawa T, Ikegami H, Yamato $E$, et al. Association of plasma fibrinogen level and blood pressure with diabetic retinopathy, and renal complications associated with proliferative diabetic retinopathy in Type 2 diabetes mellitus. Diabet Med 1999;16:522-6.

21. Neetha Kuzhuppilly IR, Vijaya Pai H. Plasma fibrinogen levels and its relation to diabetic retinopathy, Kerala Journal of Ophthalmology, Vol. XXII, No.4, Dec. 2010.

22. Klein R, Klein BE, Moss SE, et al. The Wisconsin epidemiologic study of diabetic retinopathy. III. Prevalence and risk of diabetic retinopathy when age at diagnosis is 30 or more years. Arch Ophthalmol 1984;102:527-32.

23. Frank RN, Hoffman WH, Podgor MJ, et al. Retinopathy in juvenile onset type I diabetes of short duration. Diabetes 1982;31:874-82.

24. Klein R, Klein BE, Moss SE, et al. The Wisconsin epidemiologic study of diabetic retinopathy. II. Prevalence and risk of diabetic retinopathy when age at diagnosis is less than 30 years. Arch Ophthalmol 1984;102:520-6.

25. Palmberg P, Smith M, Waltman S, et al. The natural history of retinopathy in insulin-dependent juvenile-onset diabetes. Ophthalmology 1981;88:613-8. 


\begin{tabular}{|c|c|c|c|c|c|c|c|}
\hline \multirow{2}{*}{ Age in Yrs. } & \multicolumn{2}{|c|}{ Male } & \multicolumn{2}{|c|}{ Female } & \multicolumn{2}{|c|}{ Total } & P value \\
\hline & $\mathrm{N}$ & $\%$ & $\mathrm{~N}$ & $\%$ & $\mathrm{~N}$ & $\%$ & \multirow{8}{*}{$0.204(\mathrm{NS})$} \\
\hline$\leq 40$ & 2 & 5.55 & 7 & 10.76 & 9 & 8.91 & \\
\hline $41-50$ & 8 & 22.22 & 26 & 40.00 & 34 & 33.66 & \\
\hline $51-60$ & 16 & 44.44 & 17 & 26.15 & 33 & 32.67 & \\
\hline $61-70$ & 6 & 16.66 & 11 & 16.92 & 17 & 16.83 & \\
\hline$>70$ & 4 & 11.11 & 4 & 6.15 & 8 & 7.92 & \\
\hline TOTAL & 36 & 35.64 & 65 & 64.35 & 101 & 100 & \\
\hline $\begin{array}{l}\text { Mean } \pm \text { SD } \\
\text { (Max, Min) }\end{array}$ & \multicolumn{2}{|c|}{$\begin{array}{c}57.5 \pm 10.8 \\
(32,80)\end{array}$} & \multicolumn{2}{|c|}{$\begin{array}{c}54.6 \pm 11.0 \\
(35,80)\end{array}$} & \multicolumn{2}{|c|}{$\begin{array}{c}55.6 \pm 11.0 \\
(32,80)\end{array}$} & \\
\hline
\end{tabular}

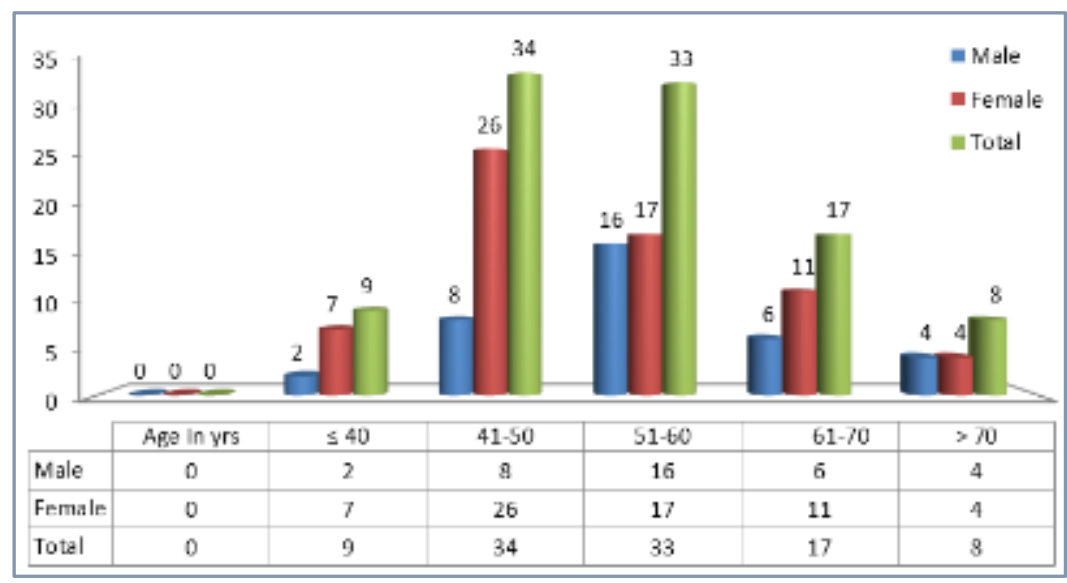

Fig. 1: Age and Gender Distribution

\begin{tabular}{|c|c|c|c|c|c|c|c|}
\hline \multirow{2}{*}{$\begin{array}{l}\text { DURATION OF } \\
\text { DIABETES (yrs.) }\end{array}$} & \multicolumn{2}{|c|}{$\begin{array}{l}\text { (Group 1) } \\
\text { WITH DR }\end{array}$} & \multicolumn{2}{|c|}{$\begin{array}{c}\text { (Group 2) } \\
\text { WITHOUT DR }\end{array}$} & \multicolumn{2}{|c|}{ Total } & \multirow[t]{2}{*}{ P-value } \\
\hline & $\mathrm{n}$ & $\%$ & $\mathrm{~N}$ & $\%$ & $\mathrm{n}$ & $\%$ & \\
\hline$\leq 5$ & 12 & 24.00 & 28 & 54.90 & 40 & 39.60 & \multirow{6}{*}{$\begin{array}{c}<0.001 \\
\text { (Sig.) }\end{array}$} \\
\hline $6-10$ & 13 & 26.00 & 17 & 33.33 & 30 & 29.70 & \\
\hline $11-15$ & 15 & 30.00 & 3 & 5.88 & 18 & 17.82 & \\
\hline $16-20$ & 10 & 20.00 & 3 & 5.88 & 13 & 12.87 & \\
\hline TOTAL & 50 & 49.50 & 51 & 50.49 & 101 & 100 & \\
\hline $\begin{array}{l}\text { Mean }+ \text { SD } \\
(\text { Max, Min) }\end{array}$ & \multicolumn{2}{|c|}{$\begin{array}{c}10.9 \pm 6.1 \\
(1.5,28)\end{array}$} & \multicolumn{2}{|c|}{$\begin{array}{l}5.7 \pm 5.0 \\
(0.1,20)\end{array}$} & \multicolumn{2}{|c|}{$\begin{array}{l}8.3 \pm 6.1 \\
(0.1,28)\end{array}$} & \\
\hline
\end{tabular}

Table 2: Duration (In yrs) of Diabetes in the Studied Subjects

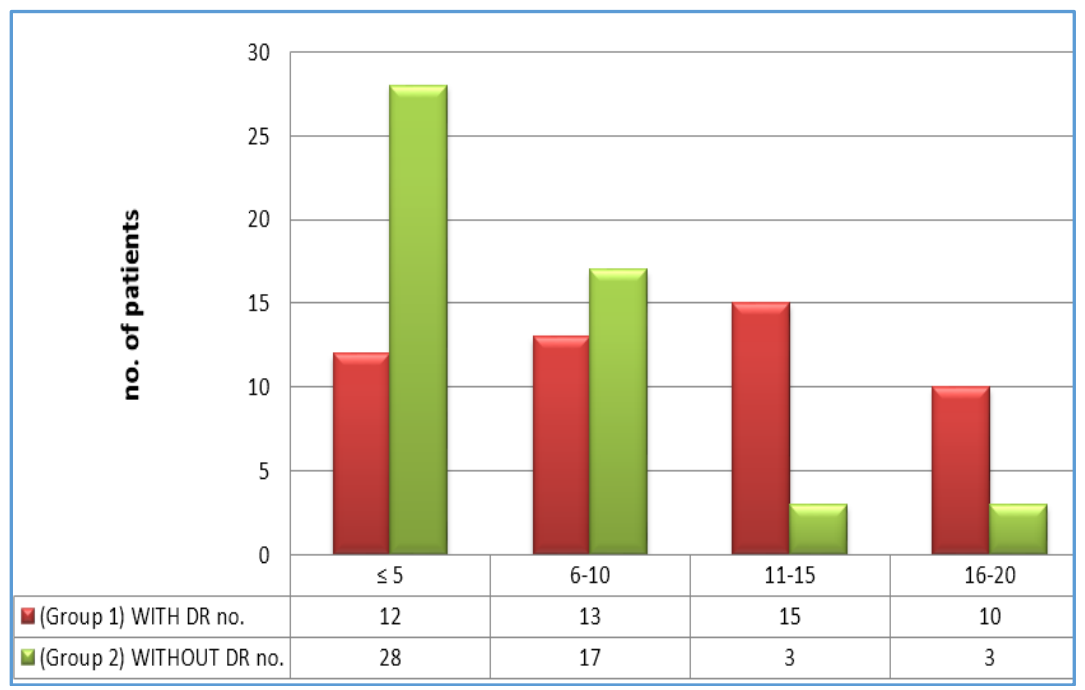

Fig. 2: Duration of Diabetes 


\begin{tabular}{|c|c|c|c|c|c|c|c|}
\hline \multirow{2}{*}{ Patients } & \multicolumn{2}{|c|}{ Male } & \multicolumn{2}{c|}{ Female } & \multicolumn{2}{c|}{ Total } & \multirow{2}{*}{ P-value } \\
\cline { 2 - 7 } & $\mathrm{n}$ & $\%$ & $\mathrm{~N}$ & $\%$ & $\mathrm{n}$ & $\%$ & \multirow{2}{*}{0.449} \\
\hline With DR & 16 & 44.4 & 34 & 52.3 & 50 & 49.5 & $(\mathrm{NS})$ \\
\hline Without DR & 20 & 55.6 & 31 & 47.7 & 51 & 5.05 & \\
\hline Total & 36 & 35.64 & 65 & 64.35 & 101 & 100 & \\
\hline
\end{tabular}

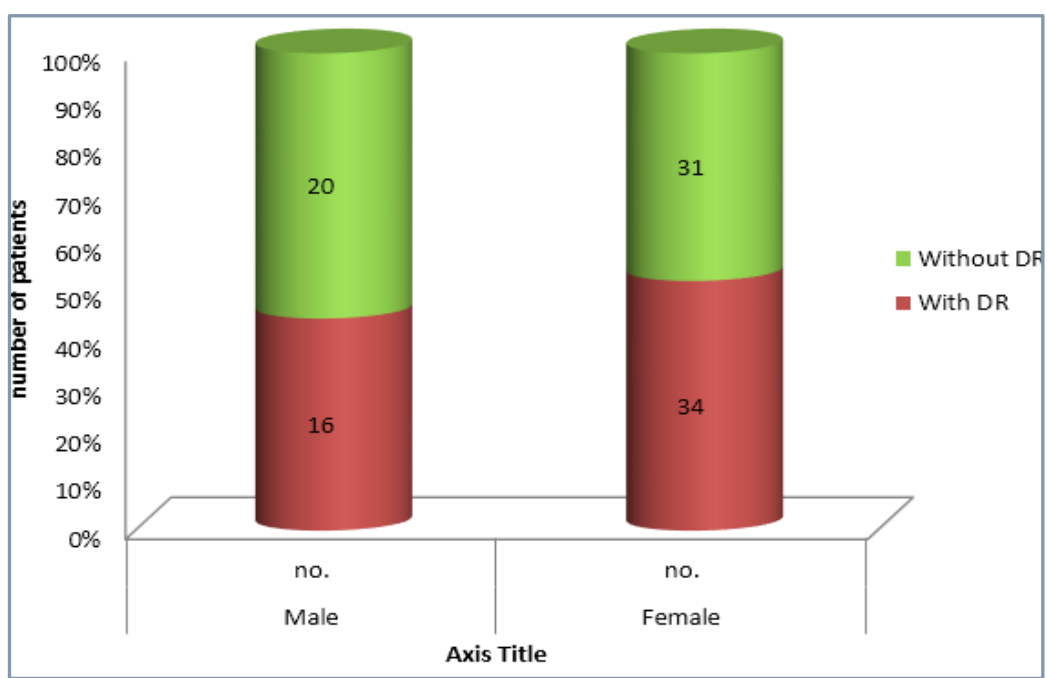

Fig. 3

\begin{tabular}{|c|c|c|c|c|}
\hline \multirow{2}{*}{ Visual Acuity } & \multicolumn{2}{|c|}{ With DR } & \multicolumn{2}{c|}{ Without DR } \\
\cline { 2 - 5 } & R Eye & L Eye & R Eye & L Eye \\
\hline 6/6 T0 6/9P & 3 & 3 & 19 & 19 \\
\hline $\mathbf{6 / 1 2}$ T0 6/18 P & 17 & 16 & 14 & 14 \\
\hline $\mathbf{6 / 2 4}$ T0 6/36 P & 13 & 11 & 14 & 15 \\
\hline$>$ 6/60 & 17 & 20 & 4 & 3 \\
\hline \multicolumn{6}{c}{ Table 4: Visual Status of Two Groups } \\
\hline
\end{tabular}

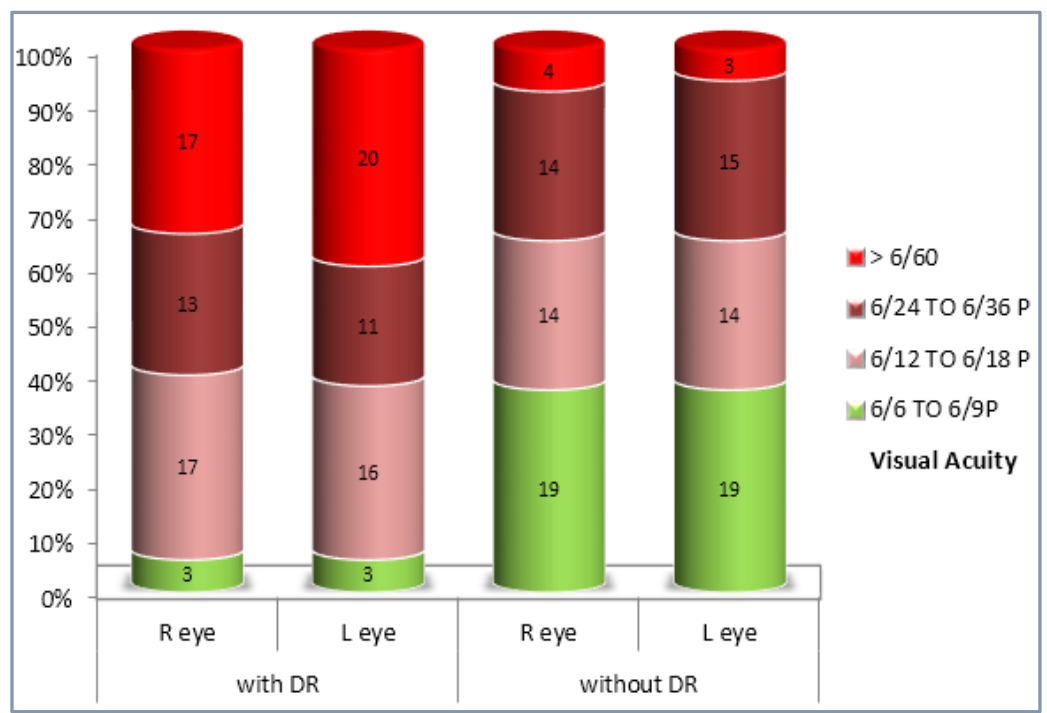

Fig. 4: Visual Acuity of Two Groups 


\begin{tabular}{|c|c|c|c|c|c|c|c|c|}
\hline \multirow{2}{*}{ Patients } & \multicolumn{2}{|c|}{ Fb Raised } & \multicolumn{2}{|c|}{ Fb Not Raised } & \multicolumn{2}{|c|}{ Total } & \multirow{2}{*}{ Fb $($ Mean \pm SD) } & P-value \\
\hline & $\mathrm{N}$ & $\%$ & $\mathrm{n}$ & $\%$ & $\mathrm{~N}$ & $\%$ & & \multirow{4}{*}{$\begin{array}{c}<0.001 \\
\text { (Sig.) }\end{array}$} \\
\hline With DR & 36 & 67.9 & 14 & 29.2 & 50 & 49.5 & $(5.310 \pm 1.734)$ & \\
\hline Without DR & 17 & 32.1 & 34 & 70.8 & 51 & 50.5 & $(3.783 \pm 1.069)$ & \\
\hline Total & 53 & 52.47 & 48 & 47.52 & 101 & 100 & & \\
\hline
\end{tabular}

Hypothesis testing: Independent samples t-test (Analysis Table)

\begin{tabular}{|c|c|c|c|c|c|c|c|c|c|}
\hline Variable & $\mathbf{N}$ & Mean & SD & Mean Difference & 95.00\% Confi & ence Interval & Cal.t & Df & p-Value \\
\hline Fb with DR & 50 & 5.310 & 1.734 & \multirow{2}{*}{1.526} & Lower Limit & Upper Limit & \multirow{2}{*}{5.336} & \multirow{2}{*}{99} & \multirow{2}{*}{$<0.001$} \\
\hline Fb without DR & 51 & 3.783 & 1.069 & & 0.959 & 2.094 & & & \\
\hline
\end{tabular}
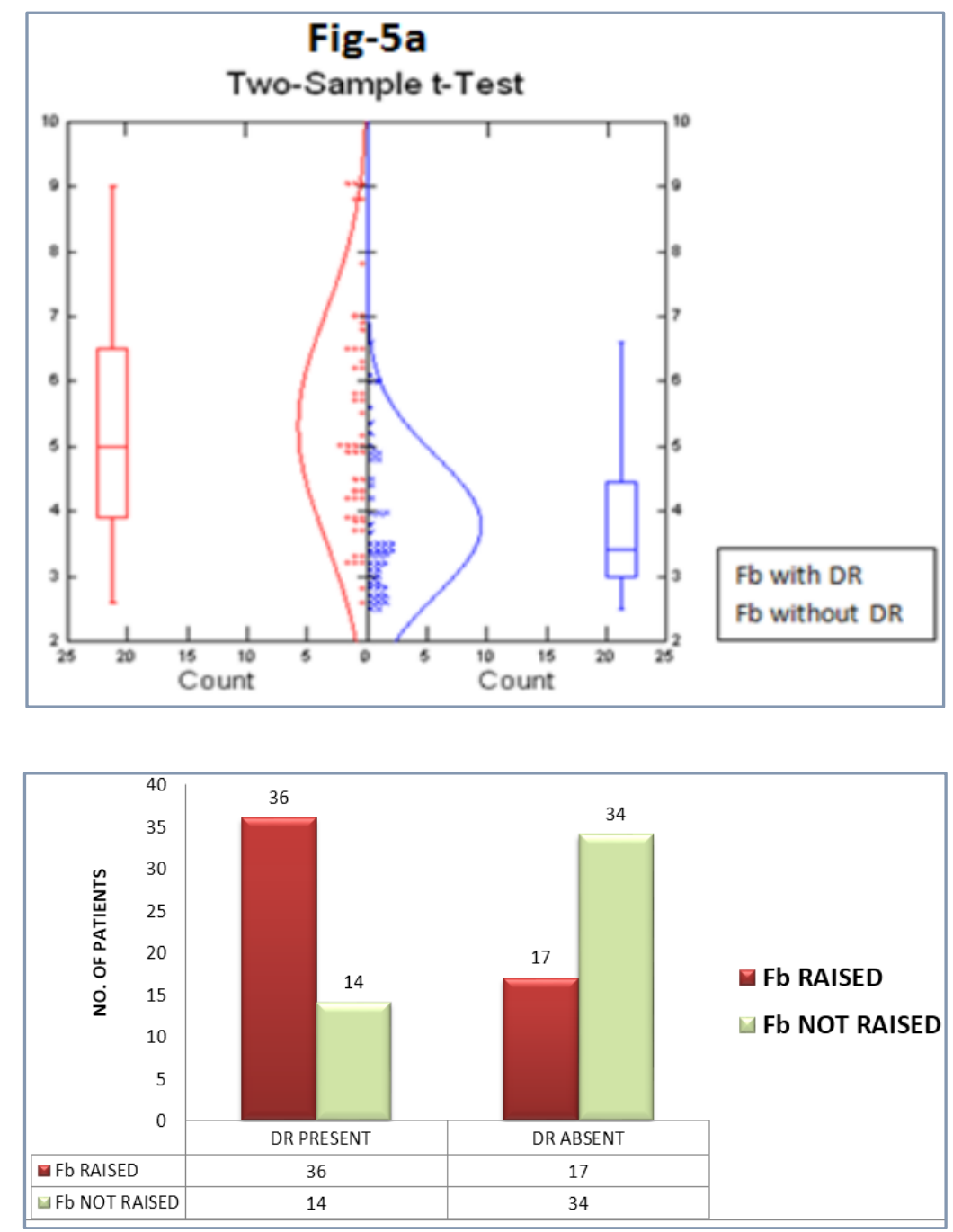

Fig. 5-b: Serum Fibrinogen Level in Relation to Diabetic Retinopathy

\begin{tabular}{|c|c|c|c|c|c|c|c|}
\hline \multirow{2}{*}{ Subjects } & \multicolumn{2}{|c|}{ Fb Raised } & \multicolumn{2}{c|}{ Fb Normal } & \multicolumn{2}{c|}{ Total } & $\begin{array}{c}\text { Fb } \\
\text { (Mean + SD) }\end{array}$ \\
\cline { 2 - 8 } & No. & $\%$ & No. & $\%$ & No. & $\%$ & \\
\hline BSF (NORMAL) & 15 & 34.88 & 28 & 65.11 & 43 & 42.57 & $\begin{array}{c}(3.995 \\
+1.475)\end{array}$ \\
\hline BSF (RAISED) & 38 & 65.51 & 20 & 34.48 & 58 & 57.42 & $\begin{array}{c}(4.942 \\
+1.621)\end{array}$ \\
\hline
\end{tabular}

Table 6: Serum Fibrinogen Levels in Relation with Fasting Blood Sugar

Hypothesis testing: Independent samples t-test (Analysis Table) 


\begin{tabular}{|c|c|c|c|c|c|c|c|c|c|}
\hline Variable & $\mathbf{N}$ & Mean & SD & $\begin{array}{l}\text { Mean } \\
\text { Difference }\end{array}$ & $\begin{array}{r}95.00 \% \\
\text { Int }\end{array}$ & $\begin{array}{l}\text { fidence } \\
\text { al }\end{array}$ & Cal.t & Df & $\begin{array}{c}\text { p- } \\
\text { Value }\end{array}$ \\
\hline $\begin{array}{c}\mathrm{Fb} \text { in BSF } \\
(\mathrm{N})\end{array}$ & 43 & 3.995 & 1.475 & \multirow{2}{*}{-0.947} & $\begin{array}{l}\text { Lower } \\
\text { Limit }\end{array}$ & $\begin{array}{l}\text { Upper } \\
\text { Limit }\end{array}$ & \multirow{2}{*}{$\begin{array}{c}- \\
3.015\end{array}$} & \multirow[b]{2}{*}{99} & \multirow[b]{2}{*}{0.003} \\
\hline $\begin{array}{c}\mathrm{Fb} \text { in } \\
\mathrm{BSF}(\mathrm{R})\end{array}$ & 58 & 4.942 & 1.621 & & -1.570 & -0.324 & & & \\
\hline
\end{tabular}

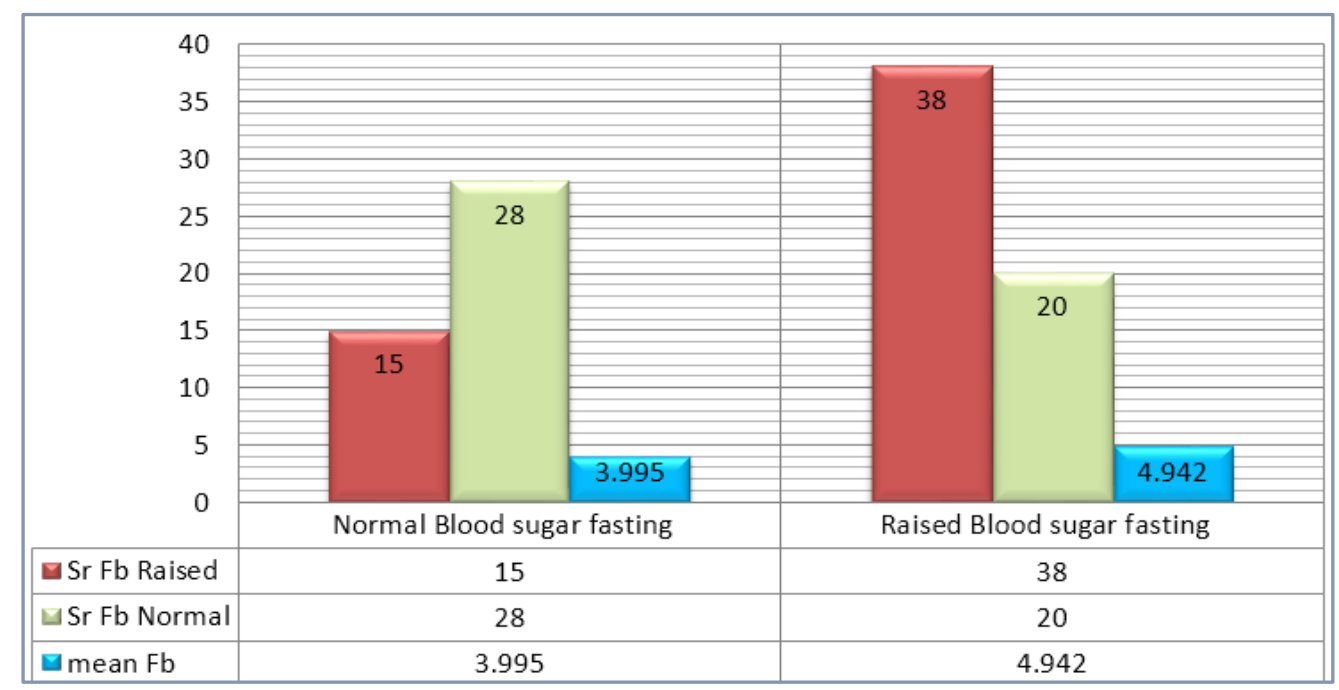

Fig. 6: Fibrinogen Level in Relation to Fasting Blood Sugar

\begin{tabular}{|c|c|c|c|c|}
\hline SEVERITY OF DR & NUMBER (n) & PERCENTAGE (\%) & Fb $($ Mean \pm SD $)$ & P-value \\
\hline NPDR & 34 & 68.00 & $5.452 \pm 1.736$ & \multirow{3}{*}{0.403} \\
\hline PDR & 16 & 32.00 & $5.007 \pm 1.686$ & \\
\hline TOTAL & 50 & & & \\
\hline
\end{tabular}

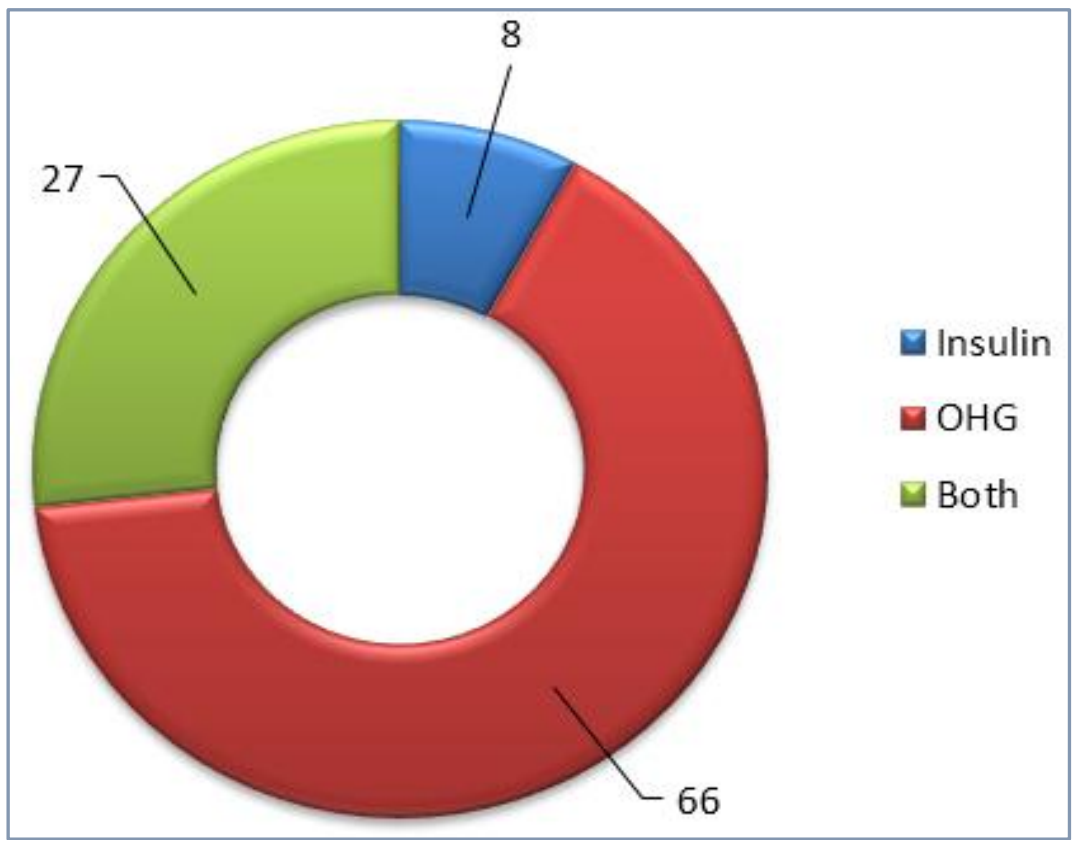

Fig-7 : Treatment Profile of Patients 


\begin{tabular}{|c|c|c|c|c|}
\hline Duration of Diabetes (YRS) & Number (n) & Percentage \% & $\begin{array}{c}\text { Fb Levels } \\
(\text { Mean } \pm \text { SD) }\end{array}$ & P-value \\
\hline$\leq 5$ & 40 & 39.60 & $(4.521 \pm 1.630)$ & \multirow{5}{*}{0.335} \\
\hline $6-10$ & 30 & 29.70 & $(4.264 \pm 1.490)$ & \\
\hline $11-15$ & 18 & 17.82 & $(5.138+1.917)$ & \\
\hline $16-20$ & 13 & 12.87 & $(4.398 \pm 1.410)$ & \\
\hline TOTAL & 101 & 100 & & \\
\hline \multicolumn{5}{|c|}{ Table 8: Serum Fibrinogen Level in Relation to Duration of Diabetes } \\
\hline
\end{tabular}

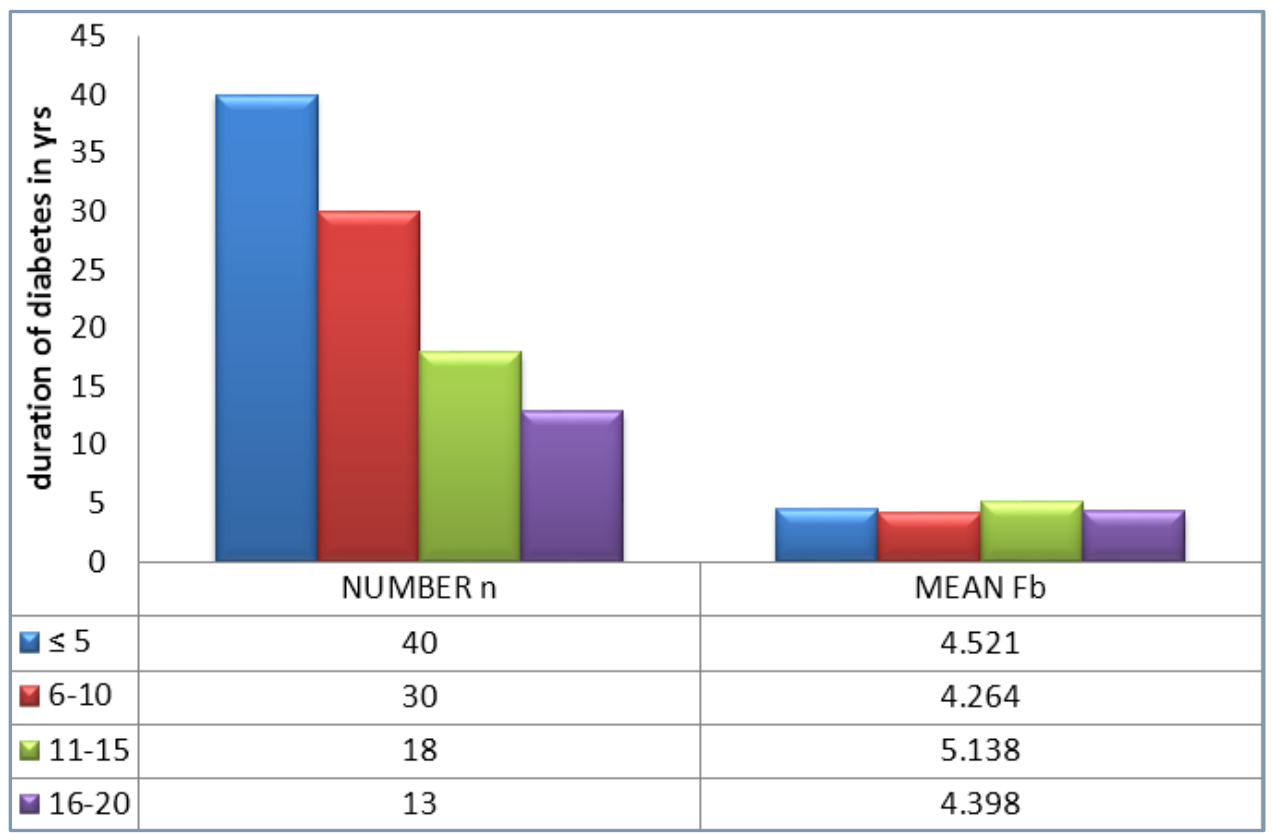

Fig. 8: Serum Fibrinogen Level in Relation to Duration of Diabetes 